\title{
Formation of Defining Ideology that Althusser Refers: Its Influences of Feminism
}

\author{
Dr. Ŭ̆ur Diler \\ Assistant Professor \\ Artuklu University, Mardin \\ Turkey
}

\begin{abstract}
Louis Althusser is known as a French Marxist Philosopher who developed different ways to look at Marx's writings from other angles because his goal was to find the problematic parts which prevented Marx's writings to be materially acknowledged and,in this way,to explain them through historical events which are concrete. Althusser's conception of ideology has affected other theories among which we can mention Feminism. As the woman is a part of the society and she is subject to any kind of ideology that puts her behind the invisible chains she can feel but cannot break. Althusser makes these chains look clearer to the eyes of the beholder by clarifying ideology and interpellation which are also adopted by Feminist writers and philosophers in a welcoming way. In this research, to define ideology that Althusser refers to and its influences of feminism.
\end{abstract}

Keywords: Louis Althusser, Feminism, ideology, Ideology and Ideological State Apparatuses, Marxism, Identity, Gender.

\section{Introduction}

When Louis Althusser's name is mentioned, it would immediately evoke in one's mind his essay: Ideology and Ideological State Apparatuses, which has become an essential text of contemporary theory because the way it deals with the issue of ideology is much more dependent than that of the Marxist teachings. In Ideology and Ideological State Apparatuses, Louis Althusser, with his manifestations, draws the author's attention to that there should be a social formation which guarentees the reproduction of the work force along with the quality and relations of the production: "Every social formation must reproduce the conditions of its production at the same time as it produces, and in order to be able to produce" (Althusser, 1970). This formation, Althusser asserts, is crucial for existence. In order to guarantee that productive forces will participate in reproduction ensured, they formed a wage system which gives workers the least amount of money possible and thus bind them to their works by forcing their showing up at work every other way. It is through the State Apparatuses that the capitalist ideology succeeds in maintaining the reproduction of "the conditions of production and the reproduction of the relations of production". These are a type of mechanisms which show themselves in the forms of repressing, taking advantage of and overpowering the class which is being ruled.

\section{Literature Review}

What is ideology? It is Cabanis, Destutt de Tracy and some of their friends who invented the term 'ideology' to which they gave the meaning of the genetic theory of ideas(Cabanis,1808\&Destutt de Tracy, 1854). Later, Marx took this word and turned its meaning to something else. Ideology became the system in which the ideas and representations have a control over the mind of people, therefore society, by leaving no question marks in their heads. That is the society cannot abstract itself from the system easily and thinks that this is the way life is and they live their daily lives. However, Marx treated ideology as something imaginary, rather dreamy and therefore it was outside of the concrete lives, histories of the individuals. On the other hand, Althusser later tried to prove the vice versa by saying ideology has a concrete history. In Be Longing: Toward a Feminist Politics of Relation, Aimee Carrillo Rowe explains Althusser's claim that ideology has concrete existence in our lives, as in the following: When we place ourselves with people aware of their oppression, we begin to see how we are implicated, to wrangle with the connections between privilege and oppression, not as abstract concepts but as constituting "our" lives.(35) 
In his essay, Louis Althusser says: "Ideology is the system of the ideas and representations which dominate the mind of man and social group"(17) and through his manifestations, goes on explaining the way ideology distances people from being individuals and makes them mere subjects within the ideological system. This is the reason why it is true to say that ideology is the representation of "the imaginary relationship of individuals to their real conditions of existence"(18). According to Louis Althusser, it is the existence of the agencies that makes the circulation of ideologies possible. Some foundations in society constitute what we call Ideological Agency which includes family, mass media, education, culture and religion. Today, the agency that circulates these ideologies is mostly the media. As an agency, for instance, the way the media functions is so subtle that people in the society are unaware of the fact that ideologies are being imposed on them. Louis Althusser gives the example of school as an instance of Ideological Agency:

"The mechanisms which produce this vital result for the capitalist regime are naturally covered up and concealed by a universally reigning ideology of the School, universally reigning because it is one of the essential forms of the ruling bourgeois ideology: an ideology which represents the School as a neutral environment purged of ideology, where teachers respectful of the 'conscience' and 'freedom' of the children who are entrusted to them by their 'parents' open up for them the path to the freedom, morality and responsibility of adults by their own example, by knowledge, literature and their 'liberating' virtues" (20).

It is the ruling classes, Althusser claims, which control the members of the society. If we are to think of a child, we may see the example of that the children are more individualistic when they are younger because they have a tendency to do what they like to do. If we are to give an example of ideology, we can talk about religion. If a person believes in God, he will do what the religion asks them to do. He will, for instance go to church or mosque. If he is Muslim, he does his prayer in the way that the religion asks him to do. Or if a Christian, he will kneel, make confessions and do the other practices that his religion wants him to do. If we ask this person if he is forced to be doing all these, he will sure say that it is his own free will and his conscience that provides him with the willingness to practice these religional actions. Here, it is possible to infer that ideology is such a system that although the person thinks that he is independent, he turns out to be not when because he does what he chooses to do or practice with the ideas in his head. If he were not to do what he thinks is good, he will not feel good and it will make him seem like he has different ideas.

Ideologies are always there and it is only when people are nurtured and they are told what is right and what is wrong by their parents that they step in the world of the ideologies and they start to behave like other people behave, they become "normal". They apprehend that there is a system that everybody else tries to obey with not much effort. They do what they are made believe by the system to be good or moral. Thus, parents bring their children up in accordance with these ideologies without the realization. Judith Butler, a feminist writer and philosopher writes in Gender Trouble Feminism And The Subversion of Identity how as a child she was "welcomed" to the world of ideologies: To make trouble was, within the reigning discourse of my chidhood, something one should never do precisely because that would get one in trouble. The rebellion and its reprimand seemed to be caught up in the same terms, a phenomenon that gave rise to my first critical insight into the subtle ruse of power: The prevailing law threatened one with trouble, even put one in trouble, all to keep one out of trouble (Butler, 1995).

The controlling classes have constructed the idea of right and wrong and imposed it on people so that they knew what they should do and they should not do. However; people unconsciously conform and think it is the way that they should live their lives and they cannot think of an alternative system. Among these ideological agencies, we can mention family, religion, education, the mass media and popular culture. Through such agencies, we are brainwashed and easily and unconsciously apprehend the pre-defined ideas about gender, sexuality, class and ethnicity and we take them for granted until we question their existence.In A Materialist Feminism Is Possible, Christine Delphy wrote and Diana Leonar reviewed as this: Ideology does not exist before the fight. What exist are ideas. Ideology obviously does not present itself as ideology: it appears as an exact reflection, as the only possible reflection of the world; as the world, in short, like all representations. Ideology is only all those representations which we denounce as false; it is not there before our denunciataon. And the denunciation must itself be based on another representation on another interpretation of the world. (100)

The power relations has its influence on everything that alienates someone from his/her real self and classifies people in terms of their gender, class, ethnicity and sexuality. When we look at the whole picture of ideological system that is created, it become clear that the person is not an individual but a subject. 
Althusser gives the example of hailing at someone in order to explain this matter of subject Louis Althusser's essay, Ideology and Ideological State Apparatuses, has affected many theories among which it is possible to mention Feminist Theory. Althusser's explanation of ideology and how it is subtly applied to every part of our lives and how it forms a bias against women helps feminists have a clearer picture of gender issue. They can argue further that the matter of gender is constructed by a system in social life. So that power relations can be kept under control, like class distinction and ethnicity, we notice that people have been also divided into two: women and men, the former being at disadvantage as the ruling class is generally in the hands of men.

Louis Althusser claims that gender is an ideological agency, which means that it is a way of controlling social formations. This immediately brings to one's mind the issue of Feminism which deals with defending the economic, social and political rights of women. As the sister of Feminism, Feminist theory came to the rescue in a more theoretical and philosophical method so that it could attain an understanding of the core matter: what is gender inequality?

Women had long had to bear to be treated as lower-class people just because of the reason that they are not men but women. The mere differences in their physiology make them inferior to men and this is again imposed by the ideology itself. Women get to wake up from these illusioned way of life when they start questioning alternative ways of life. They long been convinced that there was a problem within their gender.Concerning this, Butler tells us in the Preface ofher book, Gender Trouble Feminism And The Subversion Of Identity, her own experiences of understanding that the female was associated with the problem within the society and this was taught to her by the ideological agency when she was quite young: As time went by, further ambiguities arrived on the critical scene. I noted that trouble sometimes euphemized some fundamentally mysterious problem usually related to the alleged mystery of all things feminine.

In Be Longing: Toward a Feminist Politics of Relation, Aimee Carrillo Rowe says about gender: "For, if as Simone de Beauvoir argued long ago, "one is not born a woman, but made one"(17) (2005)-then how can we become active participants in this making? How can we become accountable for the processes which produce us? Or is it more convenient to remain continuously (re)produced as effects of power?'These questions do not strike us as something new but as they harbor irony in them. Is it not enough that women are as human and intelligent as men? Why should they be given their roles by another faculty? Aimee Carrilo Rowe, kind of, answers this question by saying in her article: "That which is most often "invisible" to groups of privilege is often most visible to those who occupy marginalized standpoints."(20)In order to apprehend what oppressed groups feel, one needs toknow about differential belonging, she continues.

Differential belonging, calls us to reckon with the ways in which we are oppressed and privileged so that we may place ourselves where we can have an impact and where we can share experience. The key to differential belonging is that you do not have to be someone, in terms defined by identity politics, in order to do the political work that differential belonging entails.( 35 , (Be)longing..)

We can clearly see that in order for power relations to be protected, differential belonging would not be applied by those who care about power because it will be against their benefit. People are born as people and an ideology spells them and turns them into men and women, the former with more adventages. Woman is called icalitya woman as she is not a man. She is born with a female phyare considered below men in the chain of beings and this makes the world of men easier as it is the women who wait for them with all their domesticity at home. The society constructs such a formation that women are unfortunately reduced to less than individuals. Thinking of that even man is reduced to subject rather than an individual which is explained through interpellation by Althusser, it becomes even more difficult to talk about a woman as a free individual with social, economic and political rights.

The power relations has its influence on everything that alienates someone from his/her real self and classifies people in terms of their gender, class, ethnicity and sexuality. When we look at the whole picture of ideological system that is created, it become clear that the person is not an individual but a subject. Althusser gives the example of hailing at someone in order to explain the matter of subject. As it is mentioned in the paragraph above, Althusser makes reference to interpellation in his essay. He says, ideology treats us as subjects rather than individuals by hailing or interpellating us :

There are individuals walking along. Somewhere (usually behind them) the hail rings out: 'Hey, you there!' One individual (nine times out often it is the right one) turns round, believing/suspecting/knowing that it is for him, i.e. recognizing that 'it really is he' who is meant by the hailing. 
But in reality these things happen without any succession. The existence of ideology and the hailing or interpellation of individuals as subjects are one and the same thing.(22)

That is, ideology does not regard us as individuals but as subjects within the social formation. Althusser stresses the eternity of ideology, by which he means that ideology has always existed and will continue existing "interpellating individuals as subjects"(22). This, he goes on, makes it clear that individuals are always-already interpellated by ideology as subjects. It is possible for us to claim that interpellation has much to do with Feminism as it makes it clear for the reader that through ideology the indiviual is interpellated and becomes a subject. This happens in the same way as ideology treats the woman and takes her individuality and makes her the subject. Here, we observe that the person is classified in terms of ideology within the society rather than his/her own self. In her article,Be Longing: Toward a Feminist Politics of Relation, Aimee Carrillo Rowe says: Louis Althusser's (1971) well-known parable of a cop hailing a subject, "hey you there!" revealsthis function of power. The subject must respond to the hailing becauseshe recognizes that it is she who is called. Whether she chooses to run from the cop, or turn and face her, whether she complies or rebels, whoshe is is constituted in her recognition that she has been hailed-her recognition of her positioning within webs of power.(16)

This is what Althusser tries to tell us about hailing. The person is the subject "within webs of power". She recognizes that she has been interpellated whatever her decision is after she realizes the police. It is only one representation of hailing, we can conclude as we readAimee Carrillo Rowe's article further. She goes on with her article by introducing us to "what Chela Sandoval (2000) calls "reverse interpellation."'(16) and how we are born into a world where we are constantly being hailed by things, groups or people we belong to.

We are always already being hailed by our various (be)longings from the moment of ourbirth, from those moments well before our births: moments of conquest and settlement, moments of miscegenation and antimiscegenation, of mixing and blending and resistance. We tend to overlook the ways that power is transmitted through our affective ties. Who we love, the communities that we live in, who we expend our emotional energies building ties with-these connections are all functions of power. So the command of this "reverse interpellation" is to call attention to the politics at stake in our belonging, and to envision an alternative.

Even who we love is shapened within the ideology, the class we are a member of and our gender. We serve the system that deals with power relations doing what we are taught to be good and moral. The child wakes up to a world where men and women get married and s/he is shocked when he realizes two people of the same gender love each other. Because it is not what he learnt and adopted as an ideology:"Whiteness and heterosexuality, forinstance, "interpellate" subjects to and through the privileges of belonging to these identity groups" ( 32 ). It is heterosexuality which is one of the key factors in keeping the balance of power rather than homosexuality as homosexuality gives harm to the idea of family by reducing the chance of reproduction of work force for the capitalist world.

\section{Conclusion}

In conclusion, ideology, according to Althusser, is the mechanism which is comprised of "the ideas and representations which dominate the mind of man and social group". With its subtle and sly temparement, its effect is much more extensive than Marx thought, according to Althusser. Marx defended that ideology is an imagination and outside of the life of the person. On the contrary, Althusser asserted that it dominates every individual's life turning him/her into subjects, which he explains by interpellation. If a police hails at us, we know that he is hailing us whatever our reaction may be and Althusser implies many things in life hail us and make us subjects rather than individuals. In our connection with other people, the government, school or a social group, we are exposed to the ideologies which urge us to behave in a way that we think is the rightest without thinking of any alternative.

Feminist theory was under the influence of the revealance of the existence of ideology because it has its benefits for Feminism as well. Many Feminist writers and philosophers wrote in relation to Althusser's way of handling ideology and could see women's being oppressed by the system very clearly. In order to protect the ties of power, the ruling class makes use of ideological agents such as education, religion, media and popular culture. Through these agents, it can brainwash people and show them its sample of ideal woman, for instance, who has to deal with everyone in the household and therefore be the powerless and domestic. We noticed in the example of Judith Butler that she learnt that women are associated with the problem when she was only a child and it goes without saying that this is how the whole society felt towards women. 
Feminism, with Althusser's assertions, tried to get answers for the inequality of men and women and could see woman's oppression better now that ideology has proved to be concrete.

\section{References}

Pierre-Jean-Georges Cabanis (1757-1808), French philosopher, author of On the Relations between the Physical and Moral Aspects of Man (1802; trans. 1981).

Destutt de Tracy (1854-1836), French philosopher, founder of the School of Ideology, pursuing a Locke-influence "science of ideas."

Althusser, Louis. Ideology and Ideological State Apparatuses. Web. <http://www.marxists.org/refere nce/archive /althusser/1970/ideology.htm>.

Butler, Judith. Conscience Doth Make Subjects of Us All. Yale French Studies No. 88, Depositions: Althusser, Balibar, Macherey, and the Labor of Reading (1995), pp. 6-26

Web. <http://www.jstor.org/stable/2930099>.

Christine, and trans. by. Leonard, Diana. A Materialist Feminism Is Possible. Web. <http://www.jstor .org/stable/1394771>

Rowe, Aimee Carrillo Be Longing. Toward a Feminist Politics of Relation.NWSA Journal,17. 2 (Summer, 2005), pp. 15-46 The Johns Hopkins University Press Stable.

<http://www.jstor.org/stable/4317124>

Butler, Judith.Gender Trouble Feminism and The Subversion Of Identity. Web.

$<$ http://autof.files.wordpress.com/2010/02/butler-judith-gender-trouble-feminism-and-the-subversion-of-identity1990.pdf>

Seiter, Ellen. Feminism and Ideology: The "Terms" of Women's Stereotypes. 22. Palgrave Macmillan JournalsStable, 58-81. Print. <http://www.jstor.org/stable/1394937>. 